\title{
Existing and emerging cyanocidal compounds: new perspectives for cyanobacterial bloom mitigation
}

\author{
Hans C. P. Matthijs • Daniel Jančula • \\ Petra M. Visser • Blahoslav Maršálek
}

Received: 31 March 2016/Accepted: 5 April 2016/Published online: 16 April 2016

(C) The Author(s) 2016. This article is published with open access at Springerlink.com

\begin{abstract}
To help ban the use of general toxic algicides, research efforts are now directed towards the discovery of compounds that are specifically acting as cyanocides. Here, we review the past and look forward into the future, where the less desirable general algicides like copper sulphate, diuron or endothall may become replaced by compounds that show better specificity for cyanobacteria and are biodegradable or transform into non-toxic products after application. For a range of products, we review the activity, the mode of action, effectiveness, durability, toxicity towards non-target species, plus costs involved, and discuss the experience with and prospects for small water volume interventions up to
\end{abstract}

Guest editors: Petra M. Visser, Bas W. Ibelings, Jutta Fastner \& Myriam Bormans/Cyanobacterial blooms. Ecology, prevention, mitigation and control.

H. C. P. Matthijs · P. M. Visser ( $₫)$

Department of Aquatic Microbiology, Institute for Biodiversity and Ecosystem Dynamics, University of Amsterdam, P.O. Box 94248, 1090 GE Amsterdam, The Netherlands

e-mail: p.m.visser@uva.nl

D. Jančula · B. Maršálek

Institute of Botany, Academy of Sciences of the Czech

Republic, Lidická 25/27, 60200 Brno, Czech Republic

B. Maršálek

RECETOX - Research Centre for Toxic Compounds in the Environment, Masaryk University, Kamenice 5, 62500 Brno, Czech Republic the mitigation of entire lakes; we arrive at recommendations for a series of natural products and extracted organic compounds or derived synthetic homologues with promising cyanocidal properties, and briefly mention emerging nanoparticle applications. Finally, we detail on the recently introduced application of hydrogen peroxide for the selective killing of cyanobacteria in freshwater lakes.

Keywords Algicides - Cyanocides · Hydrogen peroxide $\cdot$ Lake mitigation $\cdot$ Sustainability

\section{Introduction}

Eutrophication and climate change cause massive growth of cyanobacteria in water bodies across the world (Jöhnk et al. 2008; Paerl and Huisman 2008). Several publications presented in this special issue of Aquatic Ecology entitled "Cyanobacterial bloom. Ecology, prevention, mitigation and control" reflect this statement at large. Dense populations of cyanobacteria that may float on the surface of lakes are called water blooms and are regarded as a symptom of poor water quality. Nuisance is not only esthetical, a decrease in species richness also threatens biodiversity. Notably, cyanobacteria are most feared because of their potential to produce health-affecting toxins and odorous compounds that restrict the usage of lakes and of lake water for a range of ecosystem 
services of considerable importance for societal and economic interests, including drinking water, irrigation, aquaculture, fish breeding, and recreation. Cyanobacterial problems are universal and have been increasing for the last four decades. Ideally, all solutions should promote reversal of eutrophication and limit nutrient inputs into the lake from its catchment area and from diverse anthropogenic sources. Supporting methods include irreversible deposition of already-present phosphate in the lake body on its sediment with polyvalent metal ions like Al covalently attached to a mineral matrix (e.g. Jancula and Marsalek 2011a; Lürling and Oosterhout 2013). Though urgent and widely advocated, reoligotrophication solutions will also require restrictions on nutrient release in the catchment area (Cobo 2015) next to considerable engineering investments for nutrient reduction.

Independently or as a complementary effort to reoligotrophication, application of algicides is seen as a relatively fast and financially affordable control of the growth of noxious phytoplankton species. Much attention has been given in recent decades to strategies for cyanobacterial bloom management that are based on general algicidal approaches, while specific cyanocidal methods have become fashionable only more recently.

We present an inventory of algicides in "Conventional chemicals in use as algicides" section, and in "Perspectives and prospects of preferred cyanocides" section, we survey compounds that are more specific for cyanobacteria, and they are defined as cyanocides in this review. The focus is on compounds and methods that next to cyanocidal specificity demonstrate good prospects for sustainability in lake mitigation at reasonable costs. In this manuscript, sustainability and sustainable mitigation are reserved for methods of which usage facilitates lake systems to retain a diverse and productive biological state indefinitely.

\section{Conventional chemicals in use as algicides}

Conventional algicides comprise herbicides like diuron or endothall, and other algicidal compounds with copper or potassium. All feature affordable pricing, easy availability on the market, easy manipulation during applications, and last but not least all exert the desired rapid inhibitory effects on the growth of phytoplankton. However, we will discuss that these algicides demonstrate poor cyanocidal specificity and/ or fail to settle with the sustainability principle.

\section{Herbicides}

Herbicides are a group of pesticides for control of both terrestrial and aquatic plants. Since their use is based mainly on inhibition of photosynthesis, it was a legitimate assumption that such chemicals can be used in control of green algae and also cyanobacteria in lakes, reservoirs and aquaria without affecting nonphototrophic life.

Diuron (3-[3,4-dichlorophenyl]-1,1-dimethylurea) acts as an inhibitor of photosynthesis and binds to the quinone acceptor side of photosystem II in oxygenic photoautotrophs and by that blocks light-driven electron transfer (Giacomazzi and Cochet 2004). Diuron is applied in a wide concentration range from micrograms to milligrams of herbicide per litre of water (Zimba et al. 2002; Magnusson et al. 2010). Although diuron is very effective in removal of nuisance phytoplankton, it has two disadvantages:

(a) persistence in sediments (up to 1 year) (Field et al. 2003; Okamura et al. 2003), and

(b) non-selectivity, i.e. it can harm also other biota in aquatic ecosystems (Giacomazzi and Cochet 2004). Moreover, diuron is subjected to degradation in the environment, leading to formation of 3,4-DCA (3,4-dichloraniline), which is a highly toxic substance possessing genotoxic properties (Osano et al. 2002).

Endothall (7-oxabicyclo[2.2.1]heptane-2,3-dicarboxylic acid) is known as a contact herbicide currently available in many modifications, and its mode of action is through interference with RNA synthesis. Endothall acts selectively against cyanobacteria, much more so than with green algae and fish, but the relatively high toxicity towards aquatic invertebrates is problematic (Holdren et al. 2001). Endothall requires application at higher concentrations than diuron to control cyanobacterial species. It was also found that after long-term application, affected populations may build up resistance to this herbicide (Prosecka et al. 2009). 
Several other herbicides that have been tested as potential effective algicides include diquat, paraquat (Schrader et al. 1998), atrazine and simazine (Peterson et al. 1994). While these algicides are very effective as non-specific cyanocides, a warning has been published that the use of paraquat (at $1 \mathrm{mM}$ final concentration) resulted in a $90 \%$ increase in detectable cyanotoxins in the water (Ross et al. 2006). This potential cyanotoxin release from dying cells of cyanobacteria after treatment with algicides is a general problem (cf. "Concluding remarks" section at the end of this review). Otherwise, and generally speaking, the a-specific toxicity of herbicides has already limited applications and should further restrict usage in aquatic systems.

\section{Algicidal function of copper}

The application of copper-based compounds is one of the most frequently used methods to control phytoplankton abundancy. Preference for its use is based on functional effectiveness, ease of application and last but not least low costs. Copper is applied in different formulations, and next to copper sulphate, other forms like copper oxychloride, organo-copper complexes like copper ethanolamine complex (cutrine) or copper citrate are used in commercial preparations (MurrayGulde et al. 2002; Zhao et al. 2009; Qian et al. 2010; Calomeni et al. 2014). Concentrations used are in the range of hundreds of micrograms $\mathrm{Cu} \mathrm{L}^{-1}$ (Jancula and Marsalek 2011a; Fan et al. 2013). The principle of algicidal activity is through presence of bioavailable $\mathrm{Cu}^{2+}$ ion that can denature enzymes, affect membrane permeability, and decrease photosynthetic activity, phosphorus uptake, and nitrogen fixation (Zhou et al. 2013). The toxicity is not very rapidly evident and may require several days for completion, while the rate of copper disappearance to the sediment counteracts the wanted algicidal function (Qian et al. 2010).

The toxicity of copper to aquatic biota in standard laboratory conditions decreases in the order crustacean (10 $\left.\mu \mathrm{g} \mathrm{L}^{-1}\right)$, cyanobacteria $\left(20 \mu \mathrm{g} \mathrm{L}^{-1}\right)$, algae and diatoms (20-100 $\left.\mu \mathrm{g} \mathrm{L}^{-1}\right)$, rotatoria, snails, amphibians and submersed macrophytes (100-400 $\left.\mu \mathrm{g} \mathrm{L}^{-1}\right)$, up to the less sensitive organisms like fishes $\left(400 \mu \mathrm{g} \mathrm{L}^{-1}\right.$ $12 \mathrm{mg} \mathrm{L}^{-1}$ ) (Cooke et al. 2005; Zhao et al. 2009; SederColomina et al. 2013). These data and empirical observations have suggested that copper is more toxic for cyanobacteria than to other aquatic biota and that copper compounds could serve as cyanocide. However, it must be considered that the bioavailability of copper after application in aquatic ecosystems is modified by $\mathrm{pH}$, organic carbon, alkalinity, ionic strength, presence of organic (e.g. humic) substances, or conductivity and that the narrow concentration range between general algicidal and the wanted more specific cyanocidal functionality likely limits the selective application of copper as a specific cyanocide (Mastin and Rodgers 2000). It is also considered that the duration of cyanostatical effects of copper in aquatic ecosystems lasts for around 1 week only, which is due to rapid loss from the water phase through precipitation of copper as insoluble salts and hydroxylates (Cooke et al. 1993; Zhou et al. 2013; Fan et al. 2013). A need for longerterm effectiveness requires repeated treatments, creating the problem of accumulation of $\mathrm{Cu}$ in the sediment with unknown risks for potential harm to diverse benthic life (Jancula and Marsalek 2011b). Additionally, chronical application may induce resistance and cause shifts in the composition of the phytoplankton community with prevalence of copper-resistant green algae (Qian et al. 2010; Rouco et al. 2014). The ecotoxicological properties of any algicidal agent must be taken into account prior to actual in situ ecosystem application. Next to persistence of copper another issue in treatment of harmful cyanobacterial blooms is the release of cyanotoxins like microcystin-LR (MC-LR) by Microcystis aeruginosa (Jones and Orr 1994). Because this is true for all algicidal or cyanocidal compounds, the topic is discussed in some more detail in the general conclusions. The side effects of copper are seen as less desirable, and its use in ecosystems is disputable in view of sustainability principles. Despite these considerations, copper is still one of the most used algicides.

\section{Potassium chloride}

The addition of low amounts of potassium ions $\left(\mathrm{K}^{+}\right)$has been suggested as a method to selectively combat harmful cyanobacterial blooms (Parker et al. 1997; Kolmakov 2006; Shukla and Rai 2007). M. aeruginosa strain PCC 7806 appears to be more sensitive to low concentrations of potassium ions $\left(1-5 \mathrm{mmol} \mathrm{L}^{-1}\right)$ than to other alkali metal cations such as sodium (Parker et al. 1997). However, a recent survey of potassium ion sensitivity in a variety of Microcystis strains showed quite distinctive differences (Sandrini et al. 2015). Based on these results, the general cyanocidal 
effectiveness of potassium-ion is less evident and risks of less sensitive successors to take over in the ecosystem disfavour application of this cyanocide.

\section{Perspectives and prospects of preferred cyanocides}

More recently introduced algicides and cyanocides comprise chemicals and natural products that have promising potential to replace the currently used less desirable compounds discussed in "Conventional chemicals in use as algicides" section. At present, the prices of many natural products described below are usually higher than for conventional products, but in prospect the potential advantages comprise at least two desirable properties: (1) selective toxicity towards only cyanobacteria in the phytoplankton, and minimized toxicity towards non-phototropic biota and (2) biological degradation, for optimal sustainability. In "Perspectives and prospects of preferred cyanocides" section, we describe three main areas for development of such products and applications. "Natural compounds" section focuses on the use of natural compounds prior to purification and separation, "Isolated natural compounds, including synthetic homologues" section deals with more defined chemical compounds derived from the natural starting materials discussed in "Natural compounds" section, in "Nanomaterials" section, emerging prospects of nanotechnology are discussed, and "Hydrogen peroxide" section focuses on the use of hydrogen peroxide and briefly makes mention of other oxidative approaches to suppress phytoplankton.

Natural compounds

Search for effective compounds will always raise an interest in cheap and easily available natural products. Nowadays hundreds of isolated compounds or extracts thereof have been tested towards harmful phytoplankton species. Here, we review products which could one day replace conventional chemicals in the battle against cyanobacterial blooms. Most of the products discussed were tested not only in the laboratory but also in natural conditions.

\section{Barley straw}

The best known and most studied natural product used against both green algae and cyanobacteria is barley straw despite opposing results in applications and lack of convincing background information on the mechanism of action (Iredale et al. 2012). The first report about the use of barley straw as a technique to suppress the growth of harmful phytoplankton was in the $80 \mathrm{~s}$ (Welch et al. 1990; Newman and Barrett 1993; Barrett et al. 1999; Brownlee et al. 2003). The first study was not specifically against cyanobacteria, but against the green alga Cladophora glomerata in the Chesterfield canal (Welch et al. 1990). Whereas no effect on algae was observed during the first season after the introduction of straw, algae abundance decreased in the three subsequent years by $90 \%$. One of the first in situ applications took place at the Derbyshire reservoir in 1994 (Everall and Lees 1996). Addition of $50 \mathrm{~g} \mathrm{~m}^{-3}$ of barley straw appeared to control cyanobacterial growth and was stated to be due to production of unspecified phytotoxins. Moreover, the authors observed no evidence of environmental impact on other biota, and even an enhanced invertebrate productivity was noticed. However, barley straw acts in a general algistatic way and prevents growth of all phytoplankton rather than being specific against cyanobacteria. Barley straw has been added as large bales in water canals, and as minced straw or as a liquid barley extract in entire water bodies, and has in several cases shown positive effects on water quality. The combination of its relatively low price, natural origin, and general availability (also including rice straw, discussed in "Rice straw" section) has justified its choice. The method cannot yet be recommended for general applications, because (1) barley straw does not affect harmful phytoplankton immediately (which has led to quite some speculations about the mode of action which is not yet sufficiently clarified); (2) introduction of oxygen demand needed for the degradation of the biomass added to the water is a less desirable side effect that could be overcome by use of extracts; and (3) until now only few field studies have been undertaken and have presented contradictory results (Huallachain and Fenton 2010; Spencer and Lembi 2007). As an example of an unsuccessful application, we may mention a study by Prygiel et al. (2014) describing the attempt to improve the water quality at the Pont-Rouge reservoir in Northern France. Three tons of barley straw bales were introduced into the water to reach the recommended value of $50 \mathrm{~g}$ of straw per $\mathrm{m}^{3}$. Unfortunately, although the addition was performed before the summer (beginning of May), it did not prevent the formation of cyanobacterial blooms, 
though it must be remembered that it may still prove effective later in time (Welch et al. 1990).

For the mode of action of barley straw many hypotheses have been suggested. One of the first theories was the generation of hydrogen peroxide during the photooxidation of a particular constituent in the straw (Everall and Lees 1997). Iredale et al. (2012) determined that many different variables may determine the cyanocidal effects of barley straw, for example the actual cyanobacterium strains involved, the amount of UV-supplemented visible light, the temperature, the physical state of the straw used, i.e. minced or as bales, with minced material working faster, the state of decomposition of the straw, etc. They also provide clear evidence that formation of hydrogen peroxide during the photooxidation of lignin and quinone from degrading straw may exert effective cyanocidal activity. The actual cyanocidal specificity of hydrogen peroxide has in the meantime been consolidated and is discussed in the "Hydrogen peroxide" section of this review. Additionally, ellagic acid isolated from straw demonstrated significant cyanocidal effects against $M$. aeruginosa (Macioszek et al. 2010). A range of phenolic and quinone compounds extracted from barley straw has been studied. Thirty-eight compounds (earlier identified as products of barley straw decomposition) were tested (Murray et al. 2010). Results revealed highly effective cyanocidal toxicity of 2-phenylphenol, benzaldehyde, 3-methylbutanoic acid, and p-Cresol. The latest investigations showed that a pair of chiral flavonolignans called salcolin A and B demonstrated $\mathrm{EC}_{50}$ 's (concentration for $50 \%$ of maximal effect) of $6.02 \times 10^{-5}$ and $9.60 \times 10^{-5} \mathrm{~mol} \mathrm{~L}^{-1}$, respectively, against Microcystis sp. (Xiao et al. 2014). Hence, this range of compounds could very well contribute to the cyanocidal properties of barley straw.

\section{Rice straw}

Rice serves as an important food source for human being across the world, and this suggested the use of rice straw as an algicide and cyanocide very much like barley straw. Rice hull is the major by-product of milling and represents approximately $20 \%$ of the rough grain weight (Xuan et al. 2003). Rice hulls are plentiful at hand and were tested as an environmentally friendly and sustainable source for algicide production (Park et al. 2009). Unfortunately, the less abundant rice straw appeared to be more effective and selective towards cyanobacteria than hulls (Jia et al. 2014).

The first study describing the effects of rice straw on the growth of cyanobacteria was published even earlier than for barley straw (Rice et al. 1980). Lately, renewed attention was paid to this fundamental work and it was discovered that even a concentration of rice straw extract of as little as $0.01 \mathrm{mg} \mathrm{L}^{-1}$ inhibits the growth of M. aeruginosa (Park et al. 2006). In the same study, the authors also identified several chemicals which could be responsible for the inhibitory effects of rice straw on cyanobacteria. Salicylic acid was proposed although the highest inhibitory efficiency was only $26 \%$. The authors suggested that salicylic acid may act together with other (mainly phenolic) compounds found in extracts in a synergistic way. Later on, other compounds as $\beta$-sitosterol- $\beta$-Dglucoside and dicyclohexanyl orizane which powerfully inhibited growth of M. aeruginosa (66 and $80 \%$ growth inhibition for $\beta$-sitosterol- $\beta$-D-glucoside and dicyclohexanyl orizane, respectively) at concentrations of $100 \mu \mathrm{g} \mathrm{L}^{-1}$ of the particular compound, were purified. Other active compounds from rice have been isolated, but the cyanocidal efficiency of these compounds was much lower (Ahmad et al. 2013).

To date, only one study assessed the use of rice straw against a natural assemblage of cyanobacteria (Jia et al. 2014). For this study, enclosures were used $(6 \mathrm{~m} \times 5 \mathrm{~m} \times 2.2 \mathrm{~m})$ in the shallow Lake Taihu (China) to test rice straw $\left(1 \mathrm{~g} \mathrm{~L}^{-1}\right)$ and the efficiency in combination with hydrogen peroxide $\left(10 \mathrm{mg} \mathrm{L}^{-1}\right)$. In this combination, hydrogen peroxide was supposed to act as a rapid cyanocide, and rice straw was anticipated as a longer-term measure to remain active during overwintering and at the moment of recruitment of Microcystis from the sediment in spring. As a result, the biomass of cyanobacteria decreased by $27.1 \%$ during recruitment and by $53.2 \%$ of the first algal bloom compared to the year before (Jia et al. 2014). Unfortunately, the efficiency of rice straw by itself remains unknown.

Isolated natural compounds, including synthetic homologues

\section{Ephedra equisetina root extracts}

Use of purified plant extracts to control harmful algae in natural water bodies seems unrealistic because of 
limited plant material availability facing the volumetric demands of natural water bodies, yet pioneering attempts were launched by Yan et al. (2012). Authors applied root extracts into six ponds in China in a final concentration of $87.5 \mu \mathrm{L} \mathrm{L}^{-1}$ (equivalent to $1.25 \mathrm{mg} \mathrm{L}^{-1}$ of dried Ephedra equisetina root). The application was successful in terms of a significant decrease in cyanobacteria (expressed as chlorophyll$a$ concentration). The $M$. aeruginosa population in the treated ponds was reduced to values of $95-300 \mu \mathrm{g} \mathrm{L}^{-1}$ Chl- $a$, whereas the concentration in control ponds was found to be $510-680 \mu \mathrm{g} \mathrm{L}^{-1} \mathrm{Chl}-a$ (average decrease of $67 \%$ ). Moreover, it was shown that fish survival rates and fish yields in the control and treated ponds were not significantly different. In applications using extracts, the authors monitored zooplankton and macrophytes and concluded that no negative impacts on the pond ecosystems were observed and that habitat conditions for macrophytes, zooplankton, and bacterioplankton numbers even improved.

Interestingly, the extract was discovered to be more cyanocidal (causing cell death) than cyanostatical (causing inhibition of cell proliferation). Results from both in situ and in vitro trials showed destruction of the thylakoid membranes, interruption of electron transport, reduction in effective quantum yield, and cyanobacterial death (Yan et al. 2012). To this date, unfortunately, application of E. equisetina extracts has been repeated neither in situ nor in in vitro experiments, and thus, this study remains for now the only evidence of the great potential that this plant species product may have in the mitigation of cyanobacteria. Given availability of the product, applications may be especially well suited for fountains, or ornamental ponds with a low water volume.

It is recommended that research contributing to the identification and isolation of cyanocidal active compounds from plant materials will be continued. The undesirable accumulation of organic material in lakes as a negative side effect of the use of raw natural products as such can be limited in that way. In particular, attention should be paid to the selection of the raw resource for production which ideally should avoid the need for competitive use of precious crop land.

\section{Anthraquinones}

Perhaps the best known is 9,10-anthraquinone which is able to inhibit the growth of musty odour-producing cyanobacterium Oscillatoria perornata at concentrations of around $1 \mu \mathrm{M}$ under laboratory conditions (Schrader et al. 1998). Investigation of the mode of action resulted in the statement that 9,10-anthraquinone inhibits photosynthetic electron transport, probably at PSII, and thereby affects growth (Schrader et al. 2000). It also causes thylakoid disorganization (identical to the reported modification in a cyanobacterium treated with simazine) and reduces the number of ribosomes (Schrader et al. 2000). Unfortunately, this compound did not effectively reduce the abundance of cyanobacteria in catfish production ponds, possibly due to its early precipitation (Schrader et al. 2003). To provide better solubility, 9,10-anthraquinone was modified to anthraquinone-59 (2-[methylamino- $N$-(1-methylethyl)]-9,10-anthraquinone). By use of micro-titre plate bioassays, this novel compound was found to be much more selectively toxic towards $O$. perornata than diuron and copper sulphate, and in studies using limno corrals placed in catfish production ponds for gradual release, application rates of $0.3 \mu \mathrm{M}\left(125 \mu \mathrm{g} \mathrm{L}^{-1}\right)$ of the anthraquinone-59 drastically reduced the abundance of $O$. perornata and levels of 2-methylisoborneol, the musty compound produced by $O$. perornata (Schrader et al. 2003). More water-soluble anthraquinone analogues with interesting ecotoxicological properties have been synthesized recently (Nanayakkara and Schrader 2008).

\section{L-Lysine}

A first report on lysine indicated that both D- and Llysine were potent inhibitors of Microcystis sp. growth (Kaya and Sano 1996). Five years later, the L-isoform was established to be effective and the D-isoform was reported as ineffective (Zimba et al. 2001). According to Zimba et al. (2001), L-lysine was effective also against other cyanobacterial species such as Pseudanabaena articulata and Planktothrix perornata but less effective towards the green alga Scenedesmus dimorphus (Chlorophyta). Similar results were confirmed by Hehmann et al. (2002) who observed a marked inhibitory impact of L-lysine against Microcystis spp. In contrast, other cyanobacteria (Oscillatoria rubescens, Phormidium tenue) as well as Bacillariophyceae species (Melosira granulata, Cyclotella meneghiniana) and green algae (Scenedesmus acutus, Pediastrum duplex) showed much less impairment of growth after lysine addition (Hehmann et al. 2002). 
Experiments conducted in outdoor ponds next confirmed the laboratory tests. To ponds with a water volume of $20 \mathrm{~m}^{3}$ and natural Microcystis blooms, $7.3 \mathrm{mg} \mathrm{L}^{-1}$ (final concentration of L-lysin) was added and also applied on the water surface to affect floating cyanobacteria directly (Takamura et al. 2004). The Microcystis removal was rapid, already after 2 days Microcystis colonies vanished from the water surface. After the disappearance of Microcystis, Euglena sp. and/or Phormidium tenue emerged and became the dominant species in the phytoplankton community of the pond. Though the effective duration of the reduction in cyanobacteria has been indicated as short term (Lürling and Oosterhout 2014), further interrogation of this interesting cyanocide is recommended and should include sustainability aspects (increase in organic matter, cyanotoxin release), and questions about cyanobacterial strain succession as suggested by the discrepancies in strain sensitivity for L-lysine.

\section{Sanguinarine}

The effects of aqueous root extracts from species of the family Papaveraceae on the growth of cyanobacteria, algae, and non-target aquatic organisms were investigated by Jančula et al. (2007). The $\mathrm{EC}_{50}$ for Microcystis sp. was found to be 57.11 and $55.81 \mathrm{mg} \mathrm{L}^{-1}$ of root dry weight from Chelidonium majus and Dicranostigma lactucoides. Assessment of the ecotoxicological properties of isolated sanguinarine suggested that the toxicity of these root extracts (Jančula et al. 2009) was probably caused by this alkaloid. The results were confirmed by Yi et al. (2013) who isolated and tested sanguinarine from Macleay a microcarpa. Sanguinarine was active against $M$. aeruginos $a$ with a $3 \mathrm{~d}-\mathrm{EC}_{50}$ value of 0.47 and a $7 \mathrm{~d}^{-E} \mathrm{C}_{50}$ value of $0.36 \mathrm{mg} \mathrm{L}^{-1}$. In contrast, sanguinarine showed low inhibition for Chlorella pyrenoidosa and Scenedesmus obliquus with 3 d-EC50 value of $5.37 \mathrm{mg} \mathrm{L}^{-1}$ (Yi et al. 2013). Even better results were achieved by Shao et al. (2013) who determined a cyanocidal EC50 of $34.5 \mu \mathrm{g} \mathrm{L}^{-1}$ for $M$. aeruginosa strain NIES-843, and search for the potential mode of action highlighted both the donor and acceptor site of the photosystem II reaction centre to act as likely targets for inhibition by sanguinarine. In an extended analysis, damage to DNA and production of oxidative stress in actively growing cells emerged as noticeable additional effects of sanguinarine.
Nanomaterials

Nanomaterials are nowadays used in many areas of industry, medicine or in everyday life. Growing concern about a multitude of (plastic) nanomaterials to be a threat for natural ecosystems via their intensive interaction with living organisms is mentioned, but does not apply to nanoparticles of zerovalent iron (nZVI) of which the initial and functional cyanocidal effect is cell lysis and thereafter the primarily effective nZVI product is readily transformed in non-toxic aggregated $\mathrm{Fe}(\mathrm{OH})_{3}$, which promotes flocculation of the cell debris, binds residual phosphate compounds and promotes gradual settling of the cyanobacterial biomass on the sediment (Marsalek et al. 2012). The potential of the nZVI method for cyanobacterial bloom control still awaits further study, including survey of longer-term and chronic application effects.

Next to iron, also silver nanoparticles have been tested against cyanobacterial blooms. Although largescale application of nanosilver into aquatic ecosystems is hard to imagine, Park et al. (2010) tested the efficiency of nano-Ag towards $M$. aeruginosa. The study shows that $1 \mathrm{mg} \mathrm{L}^{-1}$ of nano-Ag inhibited the growth of the toxic cyanobacterium $M$. aeruginosa by $87 \%$, and similar results were obtained in field experiments. Moreover, M. aeruginosa proved to be more sensitive to silver nanoparticles than green algae were.

Nanosilicate pellets (derived from natural clay minerals) (NSP) have been suggested to act against cyanobacterial blooms and cyanobacterial toxins by Chang et al. (2014). The authors propose to use the nanosilicate material in both natural waters as well as in drinking water treatment processes. Authors stress that $M$. aeruginosa was more sensitive than other tested organisms (in particular if compared to other bacteria), but data on how more diverse aquatic species (green algae, invertebrates or fish) are affected have not been revealed till present.

\section{Hydrogen peroxide}

Natural prevalence of hydrogen peroxide (HP) in water exposed to sunlight was shown to originate from photochemical conversion of organic constituents such as humic substances (Cooper and Zika 1983), as well as from physiologically mediated synthesis (Foyer and Noctor 2008). In defence against toxic 
reactive oxygen species (ROS), green algae possess a wide repertoire of superoxide and peroxide neutralizing enzymes and the complementary reducing substrates. Examples include the co-substrate-dependent enzymes ascorbate oxidase and thioreductase, next to the reducing co-substrate-independent superoxide dismutase and catalase enzymes (Dietz 2011; Schmitt et al. 2014). The possible algicidal and cyanocidal and/ or cyanostatical activity of HP as formed during decay of barley and rice straw have been mentioned already in "Barley straw" and "Rice straw" sections of this review. The rapid degradation of HP into just water and oxygen is regarded as a great advantage in terms of sustainability in comparison with many other cyanocidal or cyanostatic substances described in earlier parts of this review. While the latter may leave permanent residues in the water or its sediment, the application of HP leaves no traces of the added chemical. A disadvantage is that handling of HP in concentrated form $(>10 \% \mathrm{w} / \mathrm{v})$ requires qualified personnel. Based on experience with present application technology (Matthijs et al. 2012), upgrading of mitigation to lakes larger than the current horizon of about 100 hectares (250 acres) is realistic.

\section{Mode of action of hydrogen peroxide}

Early pioneering research with just HP demonstrated that additions of as little as $1.75 \mathrm{mg} \mathrm{L}^{-1}$ of HP already strongly inhibited photosynthesis and growth of the cyanobacterium Oscillatoria rubescens (Barroin and Feuillade 1986). A sound explanation for the much lower sensitivity of green algae to peroxide followed from the discovery of a difference in the reaction mechanism during out-of-equilibrium-states of the photosynthetic light and dark reactions. In short, if chloroplasts (in green algae or isolated from plants) are exposed to high light or low $C_{i}$, molecular oxygen serves as an alternative photosystem I electron acceptor replacing the insufficiently regenerated $\mathrm{NADP}^{+}$. In chloroplasts of green algae, this escape route is known as the Mehler reaction (Mehler 1951). The reduction of oxygen leads to the formation of superoxide anion, which is enzymatically transformed by the enzyme superoxide dismutase into HP, the latter is subsequently degraded into just water and oxygen by catalase or peroxidase enzymes (Asada 1999; Vassilakaki and Pflugmacher 2008).
This reaction scheme is well known in plants, but quite surprisingly the similar Mehler reaction is not present in cyanobacteria and is replaced by a Mehlerlike reaction which involves two flavodiiron proteins that produce water directly (Helman et al. 2003, 2005). By consequence, no intermediary ROS compounds are formed in cyanobacteria (Allahverdiyeva et al. 2013, 2015). With no ROS compounds formed, the hypothesis was put up that for cyanobacteria the need to handle the ROS compounds superoxide and HP is less compulsory than in green algae, and hence that cyanobacteria are likely more sensitive to HP than eukaryotic algae. This fundamental idea suggested the mechanism why HP could act as a specific cyanocide which has earlier been demonstrated empirically (Barroin and Feuillade 1986). This hypothesis was thereafter successfully tested in the laboratory (Drábková et al. 2007a, b; Weenink et al. 2015) and in the field (Matthijs et al. 2012). The actual cyanobacteria killing compound may very well be not HP itself but a compound derived from HP, for which hydroxyl radical formation by UV light and catalysed by Fenton reaction active ions has been presented as a candidate by Huo et al. (2015).

HP has been empirically tested as a cyanocide and/or general algicide by a range of authors, and widely deviating dose-response observations for effectiveness of HP versus cyanobacteria in lakes range from as much as $100 \mathrm{mg} \mathrm{L}^{-1}$ (Barrington and Ghadouani 2008; Barrington et al. 2011, 2013) to around $60 \mathrm{mg} \mathrm{L}^{-1}$ (Wang et al. 2012; Gao et al. 2015), $10 \mathrm{mg} \mathrm{L}^{-1}$ (Jia et al. 2014), to $<5 \mathrm{mg} \mathrm{L}^{-1}$ (Barroin and Feuillade 1986; Drábková et al. 2007b; Matthijs et al. 2012). However, it is obvious that the higher the concentration of HP applied, the higher the killing efficiency of cyanobacteria will be, and conversely it must be argued that in lake treatments the dose should be as low as possible to avoid killing of non-target species and to respect the principle of sustainability. In the Netherlands, dosing is for that reason restricted to a maximum of $5 \mathrm{mg} \mathrm{L}^{-1}$. Till present more than ten cyanobacteria plagued Dutch lakes were treated successfully (Matthijs et al. 2012, unpublished results). Lakes had a wide variety of species diversity, in which the predetermined effective dose needed to be varied from a minimum of $2.3 \mathrm{mg} \mathrm{L}^{-1}$ in most of the Planktothrix agardhii dominated lakes to the maximally lawful upper limit of $5 \mathrm{mg} \mathrm{L}^{-1}$ in some of the Microcystis dominated lakes. Also, lakes dominated by nitrogen fixing 
cyanobacterial species Aphanizomenon and Dolichospermum (formerly called Anabaena) have by now been successfully treated with the cyanocide HP applied at 3-4 $\mathrm{mg} \mathrm{L}^{-1}$ (unpublished results). Both strain type and cell density are expected to contribute to the differences in the required dose. It is therefore recommended to estimate the minimal effective concentration the day before a treatment. In doing so, it is important to state that up to $40 \%$ of the pre-tested lake systems were regarded as not suitable for treatment because a counteracting high rate of HP degradation versus a low loss of photosynthetic vitality in the targeted cyanobacteria was beyond an empirically determined range. This range is formulated as follows: a minimum of $2 \mathrm{mg} \mathrm{L}^{-1}$ of peroxide must be retained until $5 \mathrm{~h}$ after the application of a maximal starting concentration of $5 \mathrm{mg} \mathrm{L}^{-1}$. A successful treatment characteristically demonstrates a loss of at least $80 \%$ of photosynthetic vitality (measured as photosynthetic yield loss in PAM fluorimetry of all phytoplankton) in $3-5 \mathrm{~h}$ after the peroxide application, and near to a $100 \%$ for the subgroup of cyanobacteria. In the explanation of why some lakes were considered not adequate for treatment, we mention that the cell density of the phytoplankton, and the phytoplankton species composition in the water plays an important role. In particular, the presence of eukaryotic algae (green algae and diatoms, with both algal species bearing strong anti-ROS capacity) gives rise to a high rate of HP degradation, which effectively protects cyanobacteria in the phytoplankton against oxidative damage (Weenink et al. 2015; Weenink et al. unpublished results). Also colony morphology and EPS richness play a pronounced role in resistance of cyanobacteria to an attack by HP (Lürling et al. 2014; Gao et al. 2015). Interestingly, with green algae and diatoms able to repair any relapse of their vitality within $24 \mathrm{~h}$, renewed proliferation of cyanobacteria in the water body does not take place for over 6 weeks or possibly may only occur over the course of the next growth season (Spencer and Lembi 2007; Matthijs et al. 2012; Weenink et al. 2015, unpublished results).

\section{Considerations about HP application}

As earlier evidenced for other algicides, Lürling et al. (2014) warned for lack of degradation of microcystins (MC) solubilized from HP-treated lysing cells of a laboratory strain of Microcystis. However in field experiments with the natural complement of heterotrophic microorganisms present, the total of extractable MC, i.e. the sum of particulate and water soluble fractions, rapidly decreased by more than $90 \%$ in $<3$ days (Matthijs et al. 2012). The latter observations on rapid MC degradation are supported by reports on microbial degradation of MC (Lawton et al. 2011; Dziga et al. 2013) and hydroxyl radical catalysed processing of microcystin (Huo et al. 2015).

Dissolved organic compounds from decomposing cell debris could result in higher biological and chemical oxygen demand with a risk for anaerobiosis and fish kills, which could be argued to play a less favourable role in anti-cyanocidal treatments including HP. In lake treatments with HP, this has been inspected and judged as a lesser problem than anticipated. Like the observations in the application of the cyanocide lysine by Takamura et al. (2004), debris of dead cells sank rapidly from the water surface in the water column and onwards to the sediment with clear water emerging in $<48 \mathrm{~h}$ after the treatment (unpublished results Weenink et al.). Furthermore, while HP application is advised against in case the rate of HP degradation is too high, this naturally limits the applicability in lake mitigation of denser blooms. Increasing evidence that the control of cyanobacteria after one HP application extends to the remainder of the entire season (but not into the next year as different from some of the observations with barley straw, see "Barley straw" section) should convince water managers to act timely, i.e. before the bloom becomes too dense.

It is concluded that given permissible general phytoplankton composition and cyanobacterial bloom density, homogeneously added low concentrations of HP have promising potential to act as specific cyanocide for a range of commonly encountered harmful cyanobacterial strains in freshwater lakes. Positive properties are (1) HP acts very fast, and a lake is safe for swimming (or other interrupted functionality) again after 3 days only; (2) good sustainability, no lasting chemical traces of the added HP, nor toxic substances including released cyanotoxins or particulate organic matter from dead cyanobacteria are retained in the water body (note: this statement is based on current knowledge from lake studies in the Netherlands; however, it may not hold true for each and every case, appropriate controls on toxin release and persistence should always be part of any treatment programme); (3) damage to other phyto- and 
zooplankton species is none or limited, and HP at the recommended maximal cyanocidal concentration of $5 \mathrm{mg} \mathrm{L}^{-1}$ is also safe for macrofauna, fishes and aquatic plants; (4) affordable costs. A range of questions has been formulated that still need to be answered, including effects of HP on other prokaryotes in the lake ecosystem and potential adverse effects on nutrient cycles, as well as possibilities that some cyanobacterial strains may prove resistant after all and will conquer the lake ecosystem (Dziallas and Grossart 2011; Zilliges et al. 2011). Most of all, it is stressed that for now the HP-based peroxide method for lake mitigation establishes a tool for suppression of cyanobacteria. Whether it can also be used to contribute sustainably to lake water restoration by providing conditions that help increase biodiversity (Weenink et al. 2015) and that will accelerate reoligotrophication is topic of current research at the University of Amsterdam.

\section{Other oxidative compounds with algicidal properties}

Firstly, calcium peroxide $\mathrm{CaP}$ (tradename Solvay CAS No. 1350-79-9) is a solid chemical that is often used as an oxygen-liberating additive in sediment sanitation. At lower $\mathrm{pH}$, typically around 6.5, part of the oxygen liberation is replaced by HP production. However, while HP is liberated $\mathrm{Ca}(\mathrm{OH})_{2}$ is produced, which increases the $\mathrm{pH}$ up to 11 and makes the partial HP liberation change completely to oxygen production. The intended function for the liberated oxygen is to supply bacteria that are used for degradation of xenobiotic compounds.

As a spin-off, use of slow release formulations of $\mathrm{CaP}$ has been suggested for killing of cyanobacteria locally on the sediment (Noyma et al. 2015). These applications require control of $\mathrm{CaP}$ distribution, control of the rate of HP liberation, in combination with the control of the $\mathrm{pH}$. These requirements predict that usage of $\mathrm{CaP}$ needs further investigation before application is realistic. Promising primary tests have already been published (Cho and Lee 2002).

Restraints to the admissible phytoplankton density for selective effects of HP as a cyanocide, and the reality of often encountered high bloom density during the growth season have invited treatments with compounds with strong oxidative power, including usage of higher concentrations of HP. These strong oxidant treatments do not easily qualify for lake ecosystems, but may find application in waste water processing. Fan et al. (2013) evaluated the effectiveness of chlorine, HP, ozone and potassium permanganate $\left(\mathrm{KMnO}_{4}\right)$ using SYTOX green stain permeation as a measure for changes in cell membrane permeability. All of these oxidizing compounds impair the cell membrane, and destroy cell integrity with arrest of growth of $M$. aeruginosa in dense blooms. Chlorine $\left(3 \mathrm{mg} \mathrm{L}^{-1}\right)$ showed the strongest ability to impair cell viability with cell lysis rates ranging from 0.640 to $3.82 \mathrm{~h}^{-1}$. Ozone at a dose of $6 \mathrm{mg} \mathrm{L}^{-1}$ induced $90 \%$ of the cyanobacterial cells to become permeable in 5 min only, and the cell lysis rate in presence of $\mathrm{KMnO} 4$ (at a final concentration of $10 \mathrm{mg} \mathrm{L}^{-1}$ ) was $0.829 \mathrm{~h}^{-1}$. Though the oxidative power of HP is not much different, it proved the weakest permeation agent, when added at a concentration $10 \mathrm{mg} \mathrm{L}^{-1}$ it was shown to render no more than $50 \%$ of the cells to become permeable after 1 day and about $85 \%$ of permeable cells after 2 days, after which increase in permeation changed to a reversal, with regain of cell integrity (and growth) starting at day 3 and complete recovery reached at day 7. These data agree with the observations discussed in the HP section above, where it is shown that HP effectiveness relies on the initial reaction rate; if HP action is as slow as in the Fan et al. (2013) study, reversal is indeed expected, though a mechanistic explanation and definition of the point of no return value in HP application remains to be proposed.

\section{Conclusions and discussion}

Table 1 presents a summary of compounds discussed in this review, showing their mode of action, and effectiveness as specific cyanocide, their ecosafety and related sustainability, the applicable dose range, the market price per metric ton $(1000 \mathrm{~kg})$, with some specific comments added. Note that only few of the listed compounds in Table 1 are actually indicated to be specific cyanocides, and in particular those compounds optimally fit the purpose of our survey and highlight new perspectives for selective and sustainable cyanobacterial bloom mitigation. However, next to apparent effectiveness additional aspects have to be considered before compounds can be declared suitable for sustainable application. For example, endothall renders mutants, which strongly depreciates 
Table 1 An overview of several algicidal and/or cyanocidal compounds with a description of their mode of action, their effectiveness as cyanocide, algicide and their ecosafety and related sustainability, the applicable dose range, and the estimated market price per metric ton $(1000 \mathrm{~kg})$

\begin{tabular}{|c|c|c|c|c|c|c|c|}
\hline \multirow[t]{2}{*}{ Method name } & \multirow{2}{*}{$\begin{array}{l}\text { Effect } \\
\text { Mode of action }\end{array}$} & \multicolumn{3}{|c|}{ Effectiveness } & \multirow{2}{*}{$\begin{array}{l}\text { Dose per } \\
\text { litre }\end{array}$} & \multirow[t]{2}{*}{ Price per ton } & \multirow[t]{2}{*}{ Comments } \\
\hline & & $\begin{array}{l}\text { Specific } \\
\text { cyanocide }\end{array}$ & $\begin{array}{l}\text { General } \\
\text { algicide }\end{array}$ & Ecosafety & & & \\
\hline Diuron & $\begin{array}{l}\text { Electron } \\
\text { transfer } \\
\text { blocking near } \\
\text { PSII }\end{array}$ & - & + & - & $\mu \mathrm{g}-\mathrm{mg}^{\mathrm{a}}$ & $\$ 1-100$ & $\begin{array}{l}\text { Toxic }^{\mathrm{d}} \text { degradation } \\
\text { products }\end{array}$ \\
\hline Endothall & $\begin{array}{l}\text { Protein } \\
\text { phosphatase } \\
\text { inhibitor }\end{array}$ & + & - & - & $\mathrm{mg}^{\mathrm{b}}$ & $\$ 1-100$ & Renders mutants \\
\hline Diquat & $\begin{array}{l}\text { PSI electron } \\
\text { transfer } \\
\text { interference } \\
\text { inhibition }\end{array}$ & - & + & - & $\mu \mathrm{g}-\mathrm{mg}^{\mathrm{a}}$ & $\$ 1-100$ & Toxic, persistent \\
\hline Paraquat & $\begin{array}{l}\text { PSI electron } \\
\text { transfer } \\
\text { interference } \\
\text { inhibition }\end{array}$ & - & + & - & $\mu \mathrm{g}-\mathrm{mg}^{\mathrm{a}}$ & $\$ 1-100$ & Toxic, persistent \\
\hline Atrazine & $\begin{array}{l}\text { Electron } \\
\text { transfer } \\
\text { blocking near } \\
\text { PSII }\end{array}$ & - & + & \pm & $\mu \mathrm{g}-\mathrm{mg}^{\mathrm{a}}$ & $\$ 2-16$ & Toxic, persistent \\
\hline Simazine & $\begin{array}{l}\text { Flow of } \\
\text { electrons to } \\
\text { PSI inhibitor }\end{array}$ & - & + & - & $\mu \mathrm{g}-\mathrm{mg}^{\mathrm{a}}$ & $\$ 2-200$ & Toxic, persistent \\
\hline Copper & $\begin{array}{l}\text { Substitution of } \\
\mathrm{Mg}^{2+} \text { in } \\
\text { enzyme and } \\
\text { cofactors }\end{array}$ & - & + & - & $\mu \mathrm{g}-\mathrm{mg}^{\mathrm{a}}$ & $\$ 2-5$ & $\begin{array}{l}\text { Heavy metal, lack of } \\
\text { specificity }\end{array}$ \\
\hline Iron & $\begin{array}{l}\text { Algal } \\
\text { precipitation } \\
\text { in water }\end{array}$ & - & + & + & $\mathrm{mg}^{\mathrm{b}}$ & $\$ 100-200$ & Redox labile \\
\hline Aluminm & $\begin{array}{l}\text { Algal } \\
\text { precipitation } \\
\text { in water }\end{array}$ & - & + & \pm & $\mathrm{mg}^{\mathrm{a}}$ & $\$ 100-200$ & $\begin{array}{l}\text { Prevention of free } \mathrm{Al}(\mathrm{III}) \\
\text { ion formation care for } \\
\text { alkaline } \mathrm{pH}\end{array}$ \\
\hline Potassium & $\begin{array}{l}\text { Ion balance } \\
\text { disequilibrium }\end{array}$ & + & - & - & $\mathrm{mg}^{\mathrm{a}}$ & $\$ 100-200$ & $\begin{array}{l}\text { Impact on population } \\
\text { dynamics }\end{array}$ \\
\hline Barley straw & Not clarified yet & - & + & + & $m g-g^{c}$ & $\$ 80-100$ & $\begin{array}{l}\text { Non-predictable efficacy, } \\
\text { raises BOD increase }\end{array}$ \\
\hline Rice straw & Not clarified yet & - & - & + & $m g-g^{c}$ & $\$ 100-150$ & $\begin{array}{l}\text { No proven efficacy, raises } \\
\text { BOD }\end{array}$ \\
\hline $\begin{array}{l}\text { Ephedra root } \\
\text { extract }\end{array}$ & Not clarified yet & + & $?$ & $?$ & $\mu \mathrm{g}-\mathrm{mg}$ & $\$ 30,000-40,000$ & $\begin{array}{l}\text { Special small-volume } \\
\text { purpose only, natural } \\
\text { resource }\end{array}$ \\
\hline Anthraquinones & $\begin{array}{l}\text { PSII electron } \\
\text { transport } \\
\text { inhibition }\end{array}$ & + & $?$ & $?$ & $\mu \mathrm{g}-\mathrm{mg}^{\mathrm{b}}$ & $\$ 3,000,000$ & $\begin{array}{l}\text { Special small-volume } \\
\text { purpose only; price for } \\
\text { natural resource; } \\
\text { synthetic compound is } \\
\text { cheaper }\end{array}$ \\
\hline L-Lysine & Cell lysis & \pm & - & + & $\mathrm{mg}^{\mathrm{c}}$ & $\$ 1000-2000$ & $\begin{array}{l}\text { Limited strain sensitivity } \\
\text { and effectiveness }\end{array}$ \\
\hline
\end{tabular}


Table 1 continued

\begin{tabular}{|c|c|c|c|c|c|c|c|}
\hline \multirow[t]{2}{*}{ Method name } & \multirow{2}{*}{$\begin{array}{l}\text { Effect } \\
\text { Mode of action }\end{array}$} & \multicolumn{3}{|c|}{ Effectiveness } & \multirow{2}{*}{$\begin{array}{l}\text { Dose per } \\
\text { litre }\end{array}$} & \multirow[t]{2}{*}{ Price per ton } & \multirow[t]{2}{*}{ Comments } \\
\hline & & $\begin{array}{l}\text { Specific } \\
\text { cyanocide }\end{array}$ & $\begin{array}{l}\text { General } \\
\text { algicide }\end{array}$ & Ecosafety & & & \\
\hline Sanguinarine & PSII inhibition & + & $?$ & $?$ & $\mu \mathrm{g}$ & $\$ 10,000-40,000$ & $\begin{array}{l}\text { Small-volume application } \\
\text { only }\end{array}$ \\
\hline nZVI & $\begin{array}{l}\text { Membrane } \\
\text { leaks, } \\
\text { aggregation, } \\
\text { precipitation }\end{array}$ & $?$ & + & $?$ & $\mathrm{mg}^{\mathrm{b}}$ & $\$ 35,000-150,000$ & $\begin{array}{l}\text { Fe nano particles, potential } \\
\text { membrane damage to } \\
\text { other biota? }\end{array}$ \\
\hline $\begin{array}{l}\text { Hydrogen } \\
\text { peroxide }\end{array}$ & $\begin{array}{l}\text { Cyanobacteria } \\
\text { lack sufficient } \\
\text { anti ROS } \\
\text { capacity: } \\
\text { selective cell } \\
\text { death }\end{array}$ & + & $++^{\mathrm{e}}$ & + & $\begin{array}{l}1-5 \text { (up } \\
\text { to } \\
>100) \\
\mathrm{mg}^{\mathrm{c}}\end{array}$ & $\$ 500-2000^{\mathrm{f}}$ & $\begin{array}{l}\text { In high concentration stock } \\
\text { corrosive, handling by } \\
\text { specialists only }\end{array}$ \\
\hline $\begin{array}{l}\text { Ozone, } \\
\text { chlorine, } \\
\text { permanganate }\end{array}$ & $\begin{array}{l}\text { General strong } \\
\text { Oxidative } \\
\text { damage rapid } \\
\text { membrane } \\
\text { permeation }\end{array}$ & - & + & - & $\begin{array}{l}1-10 \mathrm{mg} \\
3 \mathrm{mg} \\
10 \mathrm{mg}\end{array}$ & $\begin{array}{l}\$ 200-500^{\mathrm{g}} \\
\text { n.a. } \\
\text { n.a. }\end{array}$ & $\begin{array}{l}\text { Non-selective, algicides, } \\
\text { highly effective, complex } \\
\text { application, used for } \\
\text { drinking water and waste } \\
\text { water sanitation }\end{array}$ \\
\hline
\end{tabular}

$\overline{{ }^{a-c} \text { Educated estimate of the most probable treatment frequency: }{ }^{\mathrm{a}} \text { likely }<\text { one time yearly with occasional maintenance; }{ }^{\mathrm{b}} \text { one time, }}$ but needs continuous additional care; ${ }^{c}$ needs possibly to be repeated each year and may be even within a single growth season

d Toxic refers to effects on zooplankton invertebrates and young fish

e At higher dose

${ }^{\mathrm{f}}$ Includes costs for on site delivery, price differs per truck load or smaller volumes

$\mathrm{g}$ Ozone generator electrical power costs for on site production

its use for obvious reasons of ecosafety. Potassium salts have been applied as specific cyanocides, but may in a dose-dependent way give rise to shifts of strains and species in an existing cyanobacterial community, and thus may risk exchange for more toxic species. For compounds like Ephedra root extract, natural anthraquinones and sanguinarine price considerations may apply and be seen as out-of-scope pricewise, yet for small-volume applications these compounds may perfectly well suit the needs, and available synthetic homologues may be considered. Llysine effectiveness as a cyanocide has been reported for Microcystis, but its efficacy for other strains is less evident and growth inhibition lasts for a limited time only. HP has a proven record of specific effectiveness as a cyanocide, as cheap, but in concentrated form handling and the essential issue of homogeneous dosing of this reactive chemical in a water body needs cost-raising qualified personnel.

Several compounds listed in Table 1 have a wider range of general algicidal effectiveness. Some have the additional disadvantages of being toxic for other forms of life and being persistent in the environment. Their application will suppress not only the targeted cyanobacteria, but at the same time will kill other phytoplankton species with an important role in the biological food chain (green algae, diatoms).

Other general algicides in Table 1 have a working mechanism that may be classified as mostly primary or secondary. Primary mechanisms are those that interfere with phytoplankton by promoting mechanically forced cell lysis and resulting in direct coagulation and precipitation. To this category belong zero valency (elemental) iron particles that according to the suggested definition appear adequate as algicides. The used iron nanoparticles act only shortly as cell lysing nanoparticles and next condense to much larger iron(III) hydroxide flocks that retain activity in the deposition of biomass, a function also attributed to $\mathrm{Al}$ polyhydroxylate and zeolites. The current price for nZVI is not really promoting its actual application. Secondary mechanism examples provide rather 
cyanostatical effectiveness and include binding of phosphate by mineral-metal compounds that facilitate precipitation on the sediment of negatively charged phosphate with positively charged complexed metals (Fe, Al, La) acting as reactive entities. These P-nutrient-reducing compounds have found wide application in reduction of eutrophication (re-oligotrophication programmes) and are discussed in greater detail elsewhere in this special issue (Douglas et al. 2016). Calibrated minimal dosing and awareness of the chemical ( $\mathrm{pH}$, redox) lability of the metal-binding substances being used will contribute to improved appreciation of sustainability issues (Spears et al. 2013). Hence, proper control of the $\mathrm{pH}$ and redox conditions in all compartments of a lake is required, also considering differences between seasons in applications of metal-based general algistatic compounds.

So elegant, and so little understood is the application of barley (or rice) straw. Not only uncertainty about its effectiveness and the time span needed for actual effects are noticeable problems, but also a strong increase in organic matter that will raise the biological oxygen demand, makes it desirable that the really active compound(s) will be identified, such that extracts with these compounds can be used instead of the raw bulk material. However, costs involved in such a strategy are far from using cheap waste materials as algicide directly.

HP can be a selective cyanocide as well as a more general algicide, the difference depends on the dosing concentration. For a general algicidal function, a 5 or even 10 times higher concentration is needed than for a cyanocidal application, and use of such a higher concentration also requires special permission for lawful application, see Burson et al. (2014) describing a successful termination of a harmful dinoflagellate bloom. This application, however, differs from the mild cyanocidal approach in damaging a wider range of life in the treated water body.

A final word on recommended or rather to be discontinued usage of compounds should include considerations on price, sustainability and ecosafety of particular methods. Table 1 advises on choices that can be made. Estimates of the amount of algicidal substance needed can be made from the recommended concentrations for established applications that have been mentioned in the main text and the adhered references, plus the water volume content of the lake concerned, using the approximate product prices indicated.

A very important issue is the duration for a treatment to be completed including the aftermath of results to become apparent and the time it takes for side effects to cease, and most obviously how long the results of an intervention will last. The shorter the term, the more it loads on costs and disobeys sustainability principles. The column with applicable dose indications therefore shows the approximate application frequency in different categories in Table 1. This evaluation has been based on conclusions from literature reading and interpretation of the working mechanism. Lack of data on repeated individual treatment plans prohibit arriving at strong recommendations, and in many cases the established criteria are therefore based on an educated guess.

As may hold for all cyanocidal compounds, lysis of cells raises questions about the release of cyanotoxins into the water. For example, the use of paraquat $(1 \mathrm{mM})$ resulted in a $90 \%$ increase in detectable toxins (Ross et al. 2006). This is a potential general drawback of cyanocide application. A direct comparison of the MC-LR release potential of copper and other algicides like HP, diuron and ethyl 2-methylacetoacetate (EMA) for the four algicides showed the order $\mathrm{CuSO}_{4}>\mathrm{H}_{2} \mathrm{O}_{2}>$ diuron $>$ EMA (Zhou et al. 2013). However, it must be mentioned that concerns about toxin release associated with algicide application were based on laboratory studies using culture collection strains that may lack the cyanotoxin degrading environmental biotome (Zhou et al. 2013; Lürling et al. 2014).

The pertinent nature of cyanotoxin loss can be studied easily by estimation of the actual dynamics of the toxin content in the water after application and the time it takes for self-contained clearance of the problems. An early example of the fate of MC is presented in a study on treatment effects with copper sulphate where microcystin appeared to remain present at first, but gradually disappeared to low levels 8 days after the treatment (Jones and Orr 1994). Different cyanocides may render different results in different environments, which may also relate to the degree of lost or retained post-treatment microbial biodegradation capacity after application of a cyanocide that may affect a wider range of prokaryotes. As different from the rather slow microcystin disappearance after copper sulphate application as reported by 
Jones and Orr (1994), the actual disappearance was faster in the case of HP application where the degradation of MC took place fairly rapidly in 2-3 days (Matthijs et al. 2012, also see "Hydrogen peroxide" section).

It is recommended that for all new cyanocidal compounds, kinetic measurement of the post-treatment prevalence in the water of important cyanotoxins should be included in all studies on applications of cyanocides. These hold in particular true for those compounds that are known to be abundantly present at levels above established safety management guidelines, with MC as the key example, but also including anatoxin, cylindrospermopsin, and nodularin.

It must be stressed that for additions of compounds to water bodies and methods used regulations exist, that urge consideration of ecosafety and safety during the proper application (some of the compounds in more concentrated form are highly toxic to humans). However, quite some of those established regulations are strikingly different between countries. An example is the case of atrazine: use of atrazine is absolutely forbidden in Europe, while use is tolerated by the US EPA with strict dosage restrictions. Conversely, use of HP for entire lake experiments has been temporarily approved by EUCHEM, but individual EU governments may restrict handling of the concentrated stock by implementation of other legal safety rulings. By now, permission of HP application in the USA still differs between states. Each and every application of cyanocides needs permission in advance from legal authorities, which ideally should interpret dynamic advances in knowledge on cyanocides in the context of the applicable law. Societal needs strongly underline the urgency of continued efforts to make the precious freshwater stocks around the world healthier and more readily available for the wide range of heavily demanded ecosystem services. Besides maintenance of natural beauty and rich biodiversity, it is essential to sustain the current needs of mankind for reliable fresh water, now and in the future.

\section{Concluding remarks}

Next to a review of existing general algicidal methods, new treatments for directed suppression of uniquely cyanobacteria, i.e. that functions as cyanocide, are highlighted in this literature survey. The focus is on emerging cyanocidal methods with a sustainable nature. We emphasize that the use of cyanocides is not seen as a replacement of the principally needed efforts to stop eutrophication and enhance re-oligotrophication at large by nutrient reduction. The methods to reduce nutrient loading remain essential for sustainable lake mitigation. To our opinion, new cyanocidal methods can be used to accelerate lake restoration, with a more balanced phytoplankton community as a major attributed sustainability value. Indeed, many of the cyanocidal methods can be practiced in parallel with the reduction of nutrient loading.

Acknowledgments This study was supported as a long-term research development Project No. RVO 67985939 (Institute of Botany of the ASCR) and by the Czech Ministry of Education (LO1214).

Author's contribution Authors DJ and BM contributed the introduction, "Herbicides", "Algicidal function of copper", "Natural compounds", "Isolated natural compounds, including synthetic homologues" and "Nanomaterials" sections; authors HM and PV contributed "Potassium chloride" and "Hydrogen peroxide" section and the discussion. HM edited the manuscript. The authors are indebted to anonymous reviewers for helpful comments and to special issue editor Dr. M. Bormans for suggestions during the finalization of this manuscript. All authors have approved the final version. Authors would like to acknowledge European Cooperation in Science and Technology COST action ES1105 CYANOCOST "Cyanobacterial blooms and toxins in water resources: occurrence, impacts and management".

Open Access This article is distributed under the terms of the Creative Commons Attribution 4.0 International License (http:// creativecommons.org/licenses/by/4.0/), which permits unrestricted use, distribution, and reproduction in any medium, provided you give appropriate credit to the original author(s) and the source, provide a link to the Creative Commons license, and indicate if changes were made.

\section{References}

Ahmad A, Kim SH, Ali M, Park I, Kim JS, Kim EH, Lim JJ, Kim SK, Chung IM (2013) New chemical constituents from Oryza sativa straw and their algicidal activities against blue-green algae. J Agric Food Chem 61:8039-8048

Allahverdiyeva Y, Mustila H, Ermakova M, Bersanini L, Richaud P, Ajlani G, Battchikova N, Cournac L, Aro EM (2013) Flavodiiron proteins Flv1 and Flv3 enable cyanobacterial growth and photosynthesis under fluctuating light. PNAS 110:4111-4116

Allahverdiyeva Y, Isojärvi J, Zhang P, Aro EM (2015) Cyanobacterial oxygenic photosynthesis is protected by 
flavodiiron proteins. Life 5:716-743. doi:10.3390/ life5010716

Asada K (1999) The water-water cycle in chloroplasts: scavenging of active oxygen and dissipation of excess photons. Ann Rev Plant Biol 50:601-639

Barrett PRF, Littlejohn JW, Curnow J (1999) Long-term algal control in a reservoir using barley straw. Hydrobiologia 415:309-313

Barrington DJ, Ghadouani A (2008) Application of hydrogen peroxide for the removal of toxic cyanobacteria and other phytoplankton from wastewater. Environ Sci Technol 42:8916-8921

Barrington DJ, Ghadouani A, Ivey GN (2011) Environmental factors and the application of hydrogen peroxide for the removal of toxic cyanobacteria from waste stabilization ponds. J Environ Eng 137:952-960

Barrington D, Reichwaldt ES, Ghadouani A (2013) The use of hydrogen peroxide to remove cyanobacteria and microcystins from waste stabilization ponds and hypereutrophic systems. Ecol Eng 50:86-94

Barroin G, Feuillade G (1986) Hydrogen peroxide as a potential algicide for Oscillatoria rubescens D.C. Water Res 20:619-623

Brownlee EF, Sellner SG, Sellner KG (2003) Effects of barley straw (Hordeum vulgare) on freshwater and brackish phytoplankton and cyanobacteria. J Appl Phycol 15:525-531

Burson A, Matthijs HCP, de Bruijne W, Talens R, Hoogenboom R, Gerssen A, Visser PM, Stomp M, Steur K, Van Scheppingen Y, Huisman J (2014) Termination of a toxic Alexandrium bloom with hydrogen peroxide. Harmful Algae 31:125-135

Calomeni A, Rodgers JH Jr, Kinley CM (2014) Responses of Planktothrix agardhii and Pseudokirchneriella subcapitata to copper sulfate $\left(\mathrm{CuSO}_{4} \cdot 5 \mathrm{H}_{2} \mathrm{O}\right)$ and a chelated copper compound (Cutrine (R)-Ultra). Water Air Soil Pollut 225(12):1-15

Chang SC, Li CH, Lin JJ, Li YH, Lee MR (2014) Effective removal of Microcystis aeruginosa and microcystin-LR using nanosilicate platelets. Chemosphere 99:49-55

Cho I, Lee K (2002) Effect of calcium peroxide on the growth and proliferation of Microcystis aeruginosa, a waterblooming cyanobacterium. Biotechnol Bioprocess Eng 7:231-233

Cobo F (2015) Methods to control cyanobacteria blooms in inland waters. Limnetica 34:247-268

Cooke GD, Welch EB, Peterson SA, Newroth PR (1993) Artificial circulation. In: Cooke GD, Welch EB, Peterson SA, Newroth PR (eds) Restoration and management of lakes and reservoirs. Lewis Publishers, London, pp 419-449

Cooke GD, Welch ED, PetersonSA Nichols SA (2005) Restoration and management of lakes and reservoirs, 3rd edn. Taylor and Francis, Boca Raton

Cooper WJ, Zika RG (1983) Photochemical formation of hydrogen peroxide in surface and ground waters exposed to sunlight. Science 220:711-712

Dietz KJ (2011) Peroxiredoxins in plants and cyanobacteria. Antioxid Redox Signal 15:1129-1159

Douglas GB, Hamilton DP, Robb MS, Pan G, Spears BM, Lurling M (2016) Guiding principles for the development and application of solid-phase phosphorus adsorbents for freshwater ecosystems. Aquat Ecol. doi:10.1007/s10452016-9575-2

Drábková M, Admiraal W, Marsalek B (2007a) Combined exposure to hydrogen peroxide and light: selective effects on cyanobacteria, green algae, and diatoms. Environ Sci Technol 41:309-314

Drábková M, Matthijs HCP, Admiraal W, Marsalek B (2007b) Selective effects of $\mathrm{H}_{2} \mathrm{O}_{2}$ on cyanobacterial photosynthesis. Photosynthetica 45:363-369

Dziallas C, Grossart HP (2011) Increasing oxygen radicals and water temperature select for toxic Microcystis sp. PLoS One 6:25569

Dziga D, Wasylewski M, Wladyka B, Nybom S, Meriluoto J (2013) Microbial degradation of microcystins. Chem Res Toxicol 26:841-852

Everall NC, Lees DR (1996) The use of barley-straw to control general and blue-green algal growth in a Derbyshire reservoir. Water Res 30:269-276

Everall NC, Lees DR (1997) The identification and significance of chemicals released from decomposing barley straw during reservoir algal control. Water Res 31:614-620

Fan J, Ho L, Hobson P, Brookes J (2013) Evaluating the effectiveness of copper sulphate, chlorine, potassium permanganate, hydrogen peroxide and ozone on cyanobacterial cell integrity. Water Res 47(14):5153-5164

Field JA, Reed RL, Sawyer TE, Griffith SM, Wigington PJ (2003) Diuron occurrence and distribution in soil and surface and ground water associated with grass seed production. J Environ Qual 32:171-179

Foyer CH, Noctor G (2008) Redox regulation in photosynthetic organisms: signaling, acclimation, and practical implications. Antioxid Redox Signal 11:861-905

Gao L, Pan X, Zhang D, Mu S, Lee DJ, Halik U (2015) Extracellular polymeric substances buffer against the biocidal effect of $\mathrm{H}_{2} \mathrm{O}_{2}$ on the bloom-forming cyanobacterium Microcystis aeruginosa. Water Res 69:51-58

Giacomazzi S, Cochet N (2004) Environmental impact of diuron transformation: a review. Chemosphere 56:1021-1032

Hehmann A, Kaya K, Watanabe MM (2002) Selective control of Microcystis using an amino acid-a laboratory assay. J Appl Phycol 14:85-89

Helman Y, Tchernov D, Reinhold L, Shibata M, Ogawa T, Schwarz R, Ohad I, Kaplan A (2003) Genes encoding A-type flavoproteins are essential for photoreduction of $\mathrm{O}_{2}$ in cyanobacteria. Curr Biol 13:230-235

Helman Y, Barkan E, Eisenstadt D, Luz B, Kaplan A (2005) Fractionation of the three stable oxygen isotopes by oxygen-producing and oxygen-consuming reactions in photosynthetic organisms. Plant Physiol 138:2292-2298

Holdren C, Jones W, Taggart J (2001) Managing lakes and reservoirs. North American Lake Management Society with Terrene Institute, Madison, WI

Huallachain DO, Fenton O (2010) Barley (Hordeum vulgare)induced growth inhibition of algae: a review. J Appl Phycol 22:651-658

Huo X, Chang DW, Tseng JH, Burch MD, Lin Tsair-Fuh (2015) Exposure of Microcystis aeruginosa to hydrogen peroxide under light: kinetic modeling of cell rupture and simultaneous microcystin degradation. Environ Sci Technol 9:5502-5510 
Iredale RS, McDonald AT, Adams DG (2012) A series of experiments aimed at clarifying the mode of action of barley straw in cyanobacterial growth control. Water Res 46:6095-6103

Jancula D, Marsalek B (2011a) Seven years from the first application of polyaluminium chloride in the Czech Republic-effects on phytoplankton communities in three water bodies. Chem Ecol 28:535-544

Jancula D, Marsalek B (2011b) Critical review of actually available chemical compounds for prevention and management of cyanobacterial blooms. Chemosphere 85:1415-1422

Jančula D, Suchomelová J, Gregor J, Smutná M, Maršálek B, Táborská E (2007) Effects of aqueous extracts from five species of the family Papaveraceae on selected aquatic organisms. Environ Toxicol 22:480-486

Jančula D, Maršálek B, Novotna Z, Cerny J, Karaskova M, Rakusan J (2009) In search of the main properties of phthalocyanines participating in toxicity against cyanobacteria. Chemosphere 77:1520-1525

Jia YH, Yang Z, Su W, Johnson D, Kong FX (2014) Controlling of cyanobacteria bloom during bottleneck stages of algal cycling in shallow Lake Taihu (China). J Freshw Ecol 29:129-140

Jöhnk KD, Huisman J, Sharples J, Sommeijer B, Visser PM, Stroom JM (2008) Summer heatwaves promote blooms of harmful cyanobacteria. Glob Change Biol 14:495-512

Jones GJ, Orr PT (1994) Release and degradation of microcystin following algicide treatment of a Microcystis aeruginosa bloom in a recreational lake, as determined by HPLC and protein phosphatase inhibition assay. Water Res 28:871-876

Kaya K, Sano T (1996) Algicidal compounds in yeast extract as a component of microbial culture media. Phycologia 35:117-119

Kolmakov VI (2006) Methods for prevention of mass development of the cyanobacteria Microcystis aeruginosa Kütz emend. Elenk. in aquatic systems. Microbiology 75:149-153

Lawton L, Welgamage A, Manage P, Edwards C (2011) Novel bacterial strains for the removal of microcystins from drinking water. Water Sci Technol 63:1137-1142

Lürling M, Oosterhout FV (2013) Controlling eutrophication by combined bloom precipitation and sediment phosphorus inactivation. Water Res 47:6527-6537

Lürling M, Oosterhout FV (2014) Effect of selected plant extracts and D- and L-lysine on the cyanobacterium $\mathrm{Mi}$ crocystis aeruginosa. Water 6:1807-1825

Lürling M, Meng D, Faassen EJ (2014) Effects of hydrogen peroxide and ultrasound on biomass reduction and toxin release in the cyanobacterium, Microcystis aeruginosa. Toxins 6:3260-3280

Macioszek B, Szczukocki D, Dziegiec J (2010) Inhibition of the growth of Microcystis aeruginosa by phenolic allelochemicals from aquatic macrophytes or decomposed barley straw. Environ Eng Iii. CRC Press, Taylor \& Francis Group, Boca Raton, pp 485-489

Magnusson M, Heimann K, Quayle P, Negri AP (2010) Additive toxicity of herbicide mixtures and comparative sensitivity of tropical benthic microalgae. Mar Pollut Bull 60:1978-1987

Marsalek B, Jancula D, Marsalkova E, Mashlan M, Safarova K, Tucek J, Zboril R (2012) Multimodal action and selective toxicity of zerovalent iron nanoparticles against cyanobacteria. Environ Sci Technol 46:2316-2323
Mastin BJ, Rodgers JH (2000) Toxicity and bioavailability of copper herbicides (clearigate, cutrine-plus and copper sulfate) to freshwater animals. Arch Environ Contam Toxicol 39:445-451

Matthijs HCP, Visser PM, Reeze B, Meeuse J, Slot PC, Wijn G, Talens R, Huisman J (2012) Selective suppression of harmful cyanobacteria in an entire lake with hydrogen peroxide. Water Res 46:1460-1472

Mehler AH (1951) Studies on reactions of illuminated chloroplasts. I. Mechanism of the reduction of oxygen and other hill reagents. Arch Biochem Biophys 33:65-77

Murray D, Jefferson B, Jarvis P, Parsons SA (2010) Inhibition of three algae species using chemicals released from barley straw. Environ Technol 31:455-466

Murray-Gulde CL, Heatly JE, Schwartzmann AL, Rodgers JH (2002) Algicidal effectiveness of clearigate, cutrine-plus, and copper sulfate and margins of safety associated with their use. Arch Environ Contam Toxicol 43:19-27. doi:10. 1007/s00244-002-1135-1

Nanayakkara ND, Schrader KK (2008) Synthesis of water-soluble 9,10-anthraquinone analogues with potent cyanobactericidal activity toward the musty-odor cyanobacterium Oscillatoria perornata. J Agric Food Chem 56:1002-1007

Newman JR, Barrett PRF (1993) Control of Microcystis aeruginosa by decomposing barley straw. J Aquat Plant Manag 31:203-206

Noyma NP, de Magalhães L, Furtado LL, Mucci M, van Oosterhout F, Huszar VL, Marinho MM, Lürling M (2015) Controlling cyanobacterial blooms through effective flocculation and sedimentation with combined use of flocculants and phosphorus adsorbing natural soil and modified clay. Water Res. doi:10.1016/j.watres.2015.11.057

Okamura H, Aoyama I, Ono Y, Nishida T (2003) Antifouling herbicides in the coastal waters of western Japan. Mar Pollut Bull 47:59-67

Osano O, Admiraal W, Klamer HJC, Pastor D, Bleeker EAJ (2002) Comparative toxic and genotoxic effects of chloroacetanilides, formamidines and their degradation products on Vibrio fischeri and Chironomus riparius. Environ Pollut 119:195-202

Paerl HW, Huisman J (2008) Blooms like it hot. Science 320:57-58

Park MH, Han MS, Ahn CY, Kim HS, Yoon BD, Oh HM (2006) Growth inhibition of bloom-forming cyanobacterium $\mathrm{Mi}$ crocystis aeruginosa by rice straw extract. Lett Appl Microbiol 43:307-312

Park MH, Chung IM, Ahmad A, Kim BH, Hwang SJ (2009) Growth inhibition of unicellular and colonial Microcystis strains (Cyanophyceae) by compounds isolated from rice (Oryza sativa) hulls. Aquat Bot 90:309-314

Park MH, Kim KH, Lee HH, Kim JS, Hwang SJ (2010) Selective inhibitory potential of silver nanoparticles on the harmful cyanobacterium Microcystis aeruginosa. Biotechnol Lett 32:423-428

Parker DL, Kumar HD, Rai LC et al (1997) Potassium salts inhibit the growth of the cyanobacteria Microcystis spp. in pond water and defined media: implications for control of microcystin producing aquatic blooms. Appl Environ Microbiol 63:2324-2329

Peterson HG, Boutin C, Martin PA, Freemark KE, Ruecker NJ, Moody MJ (1994) Aquatic phyto-toxicity of 23 pesticides 
applied at expected environmental concentrations. Aquat Toxicol 28:275-292

Prosecka J, Orlov AV, Fantin YS, Zinchenko VV, Babykin MM, Tichy M (2009) A novel ATP-binding cassette transporter is responsible for resistance to viologen herbicides in the cyanobacterium Synechocystis sp. PCC 6803. FEBS J 276:4001-4011

Prygiel E, Charriau A, Descamps R, Prygiel J, Ouddane B, Billon G (2014) Efficiency evaluation of an algistatic treatment based on barley straw in a hypertrophic pond. J Environ Eng Landsc Manag 22:1-13

Qian H, Yu S, Sun Z, Xie X, Liu W, Fu Z (2010) Effects of copper sulfate, hydrogen peroxide and N-phenyl-2-naphthylamine on oxidative stress and the expression of genes involved photosynthesis and microcystin disposition in Microcystis aeruginosa. Aquat Toxicol 99:405-412

Rice EL, Lin CY, Huang CY (1980) Effects of decaying rice straw on growth and nitrogen-fixation of a blue green-alga. Bot Bull Acad Sin 21:111-117

Ross C, Santiago-Vazquez L, Paul V (2006) Toxin release in response to oxidative stress and programmed cell death in the cyanobacterium Microcystis aeruginosa. Aquat Toxicol 78:66-73

Rouco M, Lopez-Rodas V, Gonzalez R, Emma Huertas I, Garcia-Sanchez MJ, Flores-Moya A, Costas E (2014) The limit of the genetic adaptation to copper in freshwater phytoplankton. Oecologia 175(4):1179-1188

Sandrini G, Huisman J, Matthijs HCP (2015) Potassium sensitivity differs among strains of the harmful cyanobacterium Microcystis and correlates with the presence of salt tolerance genes. FEMS Microbiol Lett 362:16 art. number fnv 121

Schmitt FJ, Renger G, Friedrich T, Kreslavski VD, Zharmukhamedov SK, Los DA, Kuznetsov VV, Allakhverdiev SI (2014) Reactive oxygen species: re-evaluation of generation, monitoring and role in stress-signaling in phototrophic organisms. Biochim Biophys Acta 1837:835-848

Schrader KK, de Regt MQ, Tidwell PD, Tucker CS, Duke SO (1998) Compounds with selective toxicity towards the offflavor metabolite-producing cyanobacterium Oscillatoria cf. chalybea. Aquaculture 163:85-99

Schrader KK, Dayan FE, Allen SN, de Regt MQ, Tucker CS, Paul RN (2000) 9,10-Anthraquinone reduces the photosynthetic efficiency of Oscillatoria perornata and modifies cellular inclusions. Int J Plant Sci 161:265-270

Schrader KK, Nanayakkara NPD, Tucker CS, Rimando AM, Ganzera M, Schaneberg BT (2003) Novel derivatives of 9,10 -anthraquinone are selective algicides against the musty-odor cyanobacterium Oscillatoria perornata. Appl Environ Microbiol 69:5319-5327

Seder-Colomina M, Burgos A, Maldonado J, Sole A, Esteve I (2013) The effect of copper on different phototrophic microorganisms determined in vivo and at cellular level by confocal laser microscopy. Ecotoxicol 22:199-205

Shao J, Liu D, Gong D, Zeng Q, Yan Z, Gu JD (2013) Inhibitory effects of sanguinarine against the cyanobacterium $\mathrm{Mi}$ crocystis aeruginosa NIES-843 and possible mechanisms of action. Aquat Toxicol 142:257-263

Shukla B, Rai LC (2007) Potassium-induced inhibition of nitrogen and phosphorus metabolism as a strategy for controlling Microcystis blooms. World J Microbiol Biotechnol 23:317-322

Spears BM, Lürling M, Yasserid S, Castro-Castellone AT, Gibbs M, Meis S, McDonald C, McIntosh J, Sleeph D, van Oosterhout F (2013) Lake responses following lanthanummodified bentonite clay (Phoslock ${ }^{\circledR}$ ) application: an analysis of water column lanthanum data from 16 case study lakes. Water Res 47:5930-5942

Spencer D, Lembi C (2007) Evaluation of barley straw as an alternative algal control method in northern california rice fields. J Aquat Plant Manag 45:84-90

Takamura Y, Yamada T, Kimoto A, Kanehama N, Tanaka T, Nakadaira S, Yagi O (2004) Growth inhibition of Microcystis cyanobacteria by L-lysine and disappearance of natural $\mathrm{Mi}$ crocystis blooms with spraying. Microbes Environ 19:31-39

Vassilakaki M, Pflugmacher S (2008) Oxidative stress response of Synechocystis sp (PCC6803) due to exposure to microcystin-LR and cell-free cyanobacterial crude extract containing microcystin-LR. J Appl Phycol 20:219-225

Wang Z, Li D, Qin H, Li Y (2012) An integrated method for removal of harmful cyanobacterial blooms in eutrophic lakes. Environ Pollut 160:34-41

Weenink EF, Luimstra VM, Schuurmans JM, Van Herk MJ, Visser PM, Matthijs HCP (2015) Combatting cyanobacteria with hydrogen peroxide: a laboratory study on the consequences for phytoplankton community and diversity. Front Microbiol 6:714

Welch IM, Barrett PRF, Gibson MT, Ridge I (1990) Barley straw as an inhibitor of algal growth I: studies in the Chesterfield Canal. J Appl Phycol 2:231-239

Xiao X, Huang HM, Ge ZW, Rounge TB, Shi JY, Xu XH, Li RB, Chen YX (2014) A pair of chiral flavonolignans as novel anti-cyanobacterial allelochemicals derived from barley straw (Hordeum vulgare): characterization and comparison of their anti-cyanobacterial activities. Environ Microbiol 16:1238-1251

Xuan TD, Tsuzuki E, Terao H, Matsuo M, Khanh TD, Murayama S, Hong NH (2003) Alfalfa, rice by-products and their incorporation for weed control in rice. Weed Biol Manag 3:137-144

Yan R, Ji H, Wu Y, Kerr PG, Fang Y, Yang L (2012) An investigation into the kinetics and mechanism of the removal of cyanobacteria by extract of Ephedra equisetina root. PLoS One 7(8):e42285

Yi YL, Kang YJ, Xia L, Wang GX (2013) Growth inhibition and oxidative stress of cyanobacteria induced by sanguinarine and 6-methoxydihydrochelerythrine isolated from $\mathrm{Ma}$ cleaya microcarpa. Allelopathy J 31:211-223

Zhao XL, Song LR, Zhang XM (2009) Effects of copper sulfate treatment on eutrophic urban lake phytoplankton communities. Acta Hydrobiol Sin 33:596-602

Zhou S, Shao Y, Gao N, Deng Y, Qiao J, Ou H, Deng J (2013) Effects of different algaecides on the photosynthetic capacity, cell integrity and microcystin-LR release of $\mathrm{Mi}$ crocystis aeruginosa. Sci Total Environ 463:111-119

Zilliges Y, Kehr JC, Meissner S, Ishida K, Mikkat S, Hagemann M, Kaplan A, Börner T, Dittmann E (2011) The cyanobacterial hepatotoxin microcystin binds to proteins and increases the fitness of Microcystis under oxidative stress conditions. PLoS One 6:e17615 
Zimba PV, Dionigi CP, Brashear SS (2001) Selective toxicity of exogenous L-lysine to cyanobacteria, relative to a chlorophyte and a diatom. Phycologia 40:483-486
Zimba PV, Tucker CS, Mischke CC, Grimm CC (2002) Shortterm effect of diuron on catfish pond ecology. N Am J Aquac 64:16-23 